\title{
A report of Golovinomyces sp. on Zinnia in Iran
}

\author{
Mahdi Arzanlou ${ }^{1} \cdot{\text { Mohsen } \text { Torbati }^{1} \cdot \text { Hadi Golmohammadi }}^{1}$ \\ Received: 27 June 2018 / Accepted: 26 November 2018 / Published online: 29 November 2018 \\ (C) Australasian Plant Pathology Society Inc. 2018
}

\begin{abstract}
In November 2017, white, powdery colonies were found on leaves, stem and petals of Zinnia (Zinnia elegans) in Firouragh, the Khoy region (West Azerbaijan province), Iran. Whitish colonies, present mainly on the upper surface of the leaves, were effuse or forming patches, thin, white, and evanescent to persistent. The fungus associated with the white colonies was identified as Golovinomyces sp., based on morphological characteristics of its asexual state including conidial shape, dimension and germination pattern. Chasmothecia were not observed. The PCR amplification and sequencing of the ITS-rDNA did not differentiate our isolates from G. ambrosiae, G. spadiceus and G. circumfusus. This study provides the first report on the occurrence of Golovinomyces sp. on Z. elegans in Iran.
\end{abstract}

Keywords Euoidium type germination pattern · Golovinomyces ambrosiae · G. spadiceus

Zinnia (Zinnia elegans; Family Asteraceae) is an annual flower native to the American continent, originated from the Southwest US, Mexico and Central America. Zinnias are popular as cut flowers and as flowerbed displays all over the world. Zinnias are susceptible to a wide verity of diseases, causing economic production loss by reducing the quantity and quality of flowers. Alternaria blight caused by Alternaria zinnia, powdery mildew caused by Golovinomyces spp., and bacterial leaf spot caused by Xanthomonas campestris pv. zinnia are the major and widespread diseases of zinnia (Szopińska 2016). Several other pathogens such as Botrytis cinerea, Cercospora zinniae, Fusarium spp., Rhizoctonia solani, aster yellows phytoplasma, and several viruses may also affect zinnia (Szopińska 2016). During November 2017, powdery fungal colonies were observed on leaves, stem and petals of $Z$. elegans in several gardens at Firouragh, the Khoy region (West Azerbaijan province), Iran. Plant samples with powdery fungal colonies were collected from seven garden at different parts of the town (one specimen per garden) and taken to laboratory. Fungal masses including hyphae, conidiophores and conidia were mounted in distilled water and examined at $1000 \times$ magnification using light microscopy. Thirty measurements were made for each microscopic structure

Mahdi Arzanlou

Arzanlou@hotmail.com; Arzanlou@tabrizu.ac.ir

1 Plant Protection Department, Faculty of Agriculture, University of Tabriz, P.O. Box 5166614766, Tabriz, Iran and 95 confidence intervals were calculated for each parameter. Photographs of microscopic fungal structures were captured using an Olympus digital camera system mounted on an Olympus BX41 light microscope. Photos were edited by using Adobe Photoshop CS6 and photo plates were prepared using the same software. A dried specimen was deposited in the Fungal Herbarium of the Iranian Research Institute of Plant Protection (IRAN 17071F).

Signs of the disease appeared mainly on the upper surface of leaves and petals. The colonies were effuse or forming patches, thin, white, and evanescent to persistent on the upper leaf and flowers (Fig. 1). Later thin and effuse colonies developed on the lower side of the leaves and also on stems. On flowers whitish fungal masses developed as distinct patches on upper surface on petals. The severity of powdery mildew disease on Zinnia elegans was 100\% and diseases signs were observed on all of the plants in the sampling sites.

The fungus had the following morphology- mycelium amphigenous, also on flowers and stems, branched, septate, hyaline, thin-walled and smooth, 2-7 $\mu \mathrm{m}$ wide. Conidiophores arising from the upper surface of the mother cells, centrally or towards one end of hyphal mother cells, foot cells erect, straight, cylindrical, followed by $1-2$ shorter cells, $(40-) 56-65(-78) \times(8-) 11-12(-16) \mu \mathrm{m}$. Conidia formed in chains at the tips of conidiophores, broadly ellipsoid-ovoid, doliiform to somewhat limoniform, hyaline, (26-)33$36(-40) \times(18-) 21-24(-28) \mu \mathrm{m}$. Conidial germination pattern euoidium type, subterminal or subhilar, long, filiform, with swollen tip (70-)99-111(-125) ×(5-)6-7(-8) $\mu \mathrm{m}$ (Fig. 1). 

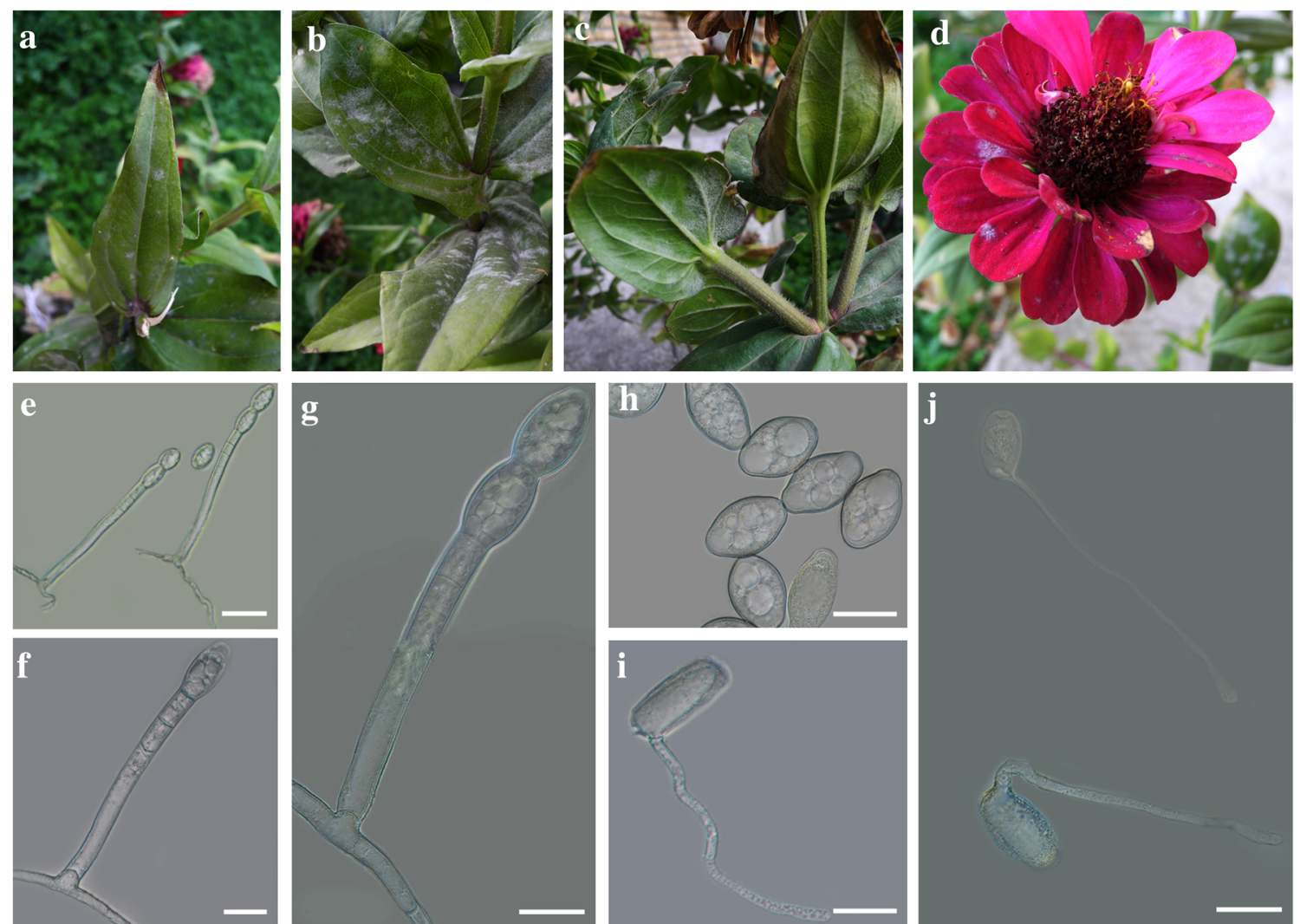

Fig. 1 Affected Zinnia (Zinnia elegans) and Golovinomyces sp. a-d disease signs on leaves, stem and flowers. e-g foot cells, conidiophores and conidial chains. $\mathbf{h}$ conidia. $\mathbf{i}-\mathbf{j}$ euoidium type conidial germination pattern. Scale: $(\mathbf{e}-\mathbf{f})=20 \mu \mathrm{m},(\mathbf{g}-\mathbf{j})=10 \mu \mathrm{m}$

Chasmothecia were not observed. Based on morphological characteristics the fungus was identified as Golovinomyces sp. (Braun and Cook 2012).

To further confirm the identity of species, a representative isolate was subjected to molecular study. The internal transcribed spacer region (ITS1-5.8S-ITS2) was amplified and sequenced using the ITS1 and ITS4 regions (White et al. 1990). Fungal DNA was exacted according the method detailed in Arzanlou et al. (2017). The reaction mixture and cycling conditions were the same as described by Arzanlou et al. (2018). A BLAST search against the nucleotide sequence data at GenBank showed $100 \%$ similarity with G. ambrosiae (Rudbeckia laciniata AB077622) and G. spadiceus (Zinnia elegans AB769425) all belonging to the composite tribe Heliantheae and G. circumfusus (Eupatorium chinense AB000934) available in GenBank. Our results are in agreement with previous studies, which have shown that ITS sequence do not possess enough variation to differentiate these closely related species (Khodaparast 2016; Meeboon et al. 2018).

Delineation of these three species based on morphological features is troublesome due to the overlap in conidial size; the conidia of $G$. circumfusus and $G$. spadiceus are
$(25-) 32-34(-40) \times(12-) 14-15(-20) \mu \mathrm{m}$ and $(25-) 32-$ $34(-40) \times(14-) 15-17(-20) \mu \mathrm{m}$ respectively which is comparable with those of G. ambrosiae, (26-)33$36(-40) \times(18-) 21-24(-28) \mu \mathrm{m}$ (Braun and Cook 2012). However, G. ambrosiae can be differentiated from G. spadiceus and G. circumfusus by its long (longitubus pattern within the Euoidium type), solitary and subterminal germ tubes and broader conidia (Braun and Cook 2012). The germination pattern of conidia for our isolates was in agreement with G. ambrosiae. As both G. ambrosiae and G. spadiceus have been reported to occur on Zinnia spp., their differentiation based only on conidial germination pattern is not reliable. The sequence obtained in this study is available in GenBank with the accession number MH699992. A dried specimen was deposited in the Fungal Herbarium of the Iranian Research Institute of Plant Protection (IRAN 17071F). Until now several Golovinomyces species have been reported from wide ranges of plant species in Iran (Khodaparast and Abbasi 2009; Khodaparast 2016); of those, G. spadiceus has been reported on Dahlia. To the best of our knowledge, this is first report on the occurrence of a Golovinomyces species on Zinnia elegans in Iran (Khodaparast and Abbasi 2009; Khodaparast 2016). 
Acknowledgements We thank the Research Deputy of the University of Tabriz, for financial support.

\section{References}

Arzanlou M, Torbati M, Narmani A (2017) Podosphaera clandestina causes powdery mildew on sour cherry in Iran. Aust Plant Dis Notes 12(1). https://doi.org/10.1007/s13314-017-0231-z

Arzanlou M, Torbati M, Golmohammadi H (2018) Powdery mildew on hazelnut (Corylus avellana) caused by Erysiphe corylacearum in Iran. For Pathol:e12450. https://doi.org/10.1111/efp.12450

Braun U, Cook RTA (2012) Taxonomic manual of the Erysiphales (powdery mildew). CBS Biodivers Ser 11:1-707

Khodaparast SA (2016) Molecular identification of some anamorphic powdery mildews (Erysiphales) in Guilan province, north of Iran. Mycol Iran 3(2):127-133. https://doi.org/10. 22043/mi.2017.68336.1095

Khodaparast SA, Abbasi M (2009) Species, host range and geographical distribution of powdery mildew fungi (Ascomycota: Erysiphales) in Iran. Mycotaxon 108:213-216

Meeboon J, Kokaew J, Takamatsu S (2018) Notes on powdery mildews (Erysiphales) in Thailand V. Golovinomyces. Trop Plant Pathol 43:202-217

Szopińska D (2016) Diseases of Zinnia. In: McGovern RJ, Elmer WH (eds) Handbook of Florists' crops diseases. Springer International Publishing, Switzerland

White TJ, Bruns TD, Lee SB, Taylor JW (1990) Amplification and sequencing of fungal ribosomal RNA genes for phylogenetics. In: Innis N, Gelfand D, Sninsky J, White TC (eds) PCR protocols and applications - a laboratory manual. Academic Press, New York 